\title{
Assessment of knowledge regarding tuberculosis among non-medical university students in Bangladesh: a cross-sectional study
}

\author{
Masud Rana', Abu Sayem²*, Reazul Karim³ ${ }^{3}$ Nurul Islam ${ }^{4}$, Rafiqul Islam¹, Tunku Kamarul Zaman ${ }^{5}$ \\ and Golam Hossain ${ }^{4}$
}

\begin{abstract}
Background: Tuberculosis (TB) is the second leading cause of human death and TB is one of the major public health problems in Bangladesh. The aim of the present study was to assess the Knowledge about TB among non-medical university students in Bangladesh.

Methods: A cross-sectional survey was performed on 839 non-medical university students. Data were collected from University of Rajshahi from March to August 2013 using a standard semi-structured questionnaire. Chi-square test was utilized to find the factors which are associated with students' knowledge about TB.

Results: Among 839 students, male and female were $68.2 \%$ and $31.8 \%$ respectively. Most of the students (94.4 \%) were informed about the term TB, among them $50 \%$ got information from electronic media. More than $50 \%$ students believed that TB is a communicable disease, $42.8 \%$ students agreed that bacteria is an agent for TB, most of the subjects (93\%) had the knowledge about the vaccination against TB and $97.6 \%$ students believed that TB is curable. However, students had poor knowledge about latent TB (13.7\%) and DOTs program (28.5\%). $x^{2}$-test demonstrated that gender, residence, type of family and parents education were associated with students' knowledge of TB.

Conclusion: In the present study demonstrated that the level of general knowledge about TB was insufficient among non-medical university students. Consequently, health education program is needed to improve the knowledge among university students regarding TB.
\end{abstract}

Keywords: Tuberculosis, Knowledge, Non-medical university students, Socio-economic factors, $X^{2}$-test

\section{Background}

In 1993, World Health Organization (WHO) declared that tuberculosis (TB) is a global emergency as because more than two billion people in the world is infected with mycobacterium tuberculosis, and they have the chance of developing TB at any stages of life. Furthermore, the infection rate is higher in developing countries like Bangladesh. TB is the second leading cause of death after human immune deficiency virus (HIV), as the greatest killer worldwide due to a single infectious agent [1]. Every year, more than 1.3 million people die around the world due to TB [2]. $82 \%$ deaths occur in 22 high burden countries (HBCs)

\footnotetext{
* Correspondence: sayem072003@yahoo.com

${ }^{2}$ Divisional TB Expert, National Tuberculosis Control Program, Directorate General of Health Services, Dhaka, Bangladesh

Full list of author information is available at the end of the article
}

and Bangladesh rank $6^{\text {th }}$ among HBCs. Low awareness, education, income and high population density, smoking, diabetes, certain drugs and other associated diseases are the contributory factors for TB in Bangladesh [1]. The Government of Bangladesh, under the Ministry of Health and Family Welfare, Directorate General of Health Services (DGHS) are providing free diagnostic and treatment support to all irrespective of age, race, sex, occupation, geography or education through its National Tuberculosis Control Program (NTP). The Government of Bangladesh is also conducting different sessions, seminars, workshops, meeting, conferences, orientation on TB from 1993 using mass media and other media to aware the people at all level. Though Bangladesh has adopted internationally recommended Directly Observed Treatments Short Course (DOTs) strategy in 
1993 [1] and STOP TB strategy in 2006 for effective control of TB in Bangladesh and also achieved more than $92 \%$ treatment success rate through public private partnership and involvement of huge health care providers [1]. Still it requires more attention on knowledge and awareness of the community people regarding many areas; especially about diagnostic and treatment service opportunities, availability of services, mode of transmission, effect as well as impact of disease, DOTs, type of disease etc. Without proper diagnosis in early stage and irregularity of treatment can be a serious threat for the country as a whole due to chance of increasing spread and development of drug resistant (DR) TB. The DR-TB is a double burden for the society due to more duration of sufferings, high treatment cost and more chance of deaths. People at all levels need to be aware for early health seeking and regularity of treatment. Several studies have surveyed the knowledge about TB and they reported that poor knowledge, attitudes and practices regarding TB among general population [3, 4], among pre-university students $[5,6]$, high and secondary school students $[7,8]$. Most of the surveys took place among medical students, health care workers and other occupation [9-13]. However, some researchers have surveyed the knowledge about TB among non-medical university students in other countries $[14,15]$. We assume that a significant portion of middle and higher educated people have poor knowledge on TB including non-medical university students in Bangladesh. On the other hand, there is no survey on level of knowledge and awareness about TB among non-medical university students in Bangladesh. Particularly with respect to Bangladeshi populations one study has surveyed the knowledge about $\mathrm{TB}$ transmission among ever-married women in Bangladesh [16]. Another study has surveyed knowledge about TB in two areas in northern Bangladesh to assess and compare the level of knowledge, attitude and practice towards leprosy and TB among two communities [17]. Special attention should be paid to university students considering their potential influence on the family and their contribution to the nation's workforce in near future in a particular nation. Due to their unique role in near future in the society, it is important to investigate the knowledge about communicable disease like TB. Considering the level of knowledge on common symptoms, disease agent, type of disease, latent infection, source of gaining knowledge, vaccination against $\mathrm{TB}$, treatment system is fundamental information about TB which is necessary to analyze. Association between the knowledge about TB among non-medical university students and socio-economic factors such as gender, religion, residence, parents' education, occupation and income, type of family, in order to ensure corrective measures can be undertaken.
Therefore, the objective of this study is to assess the knowledge about TB among non-medical university students in Bangladesh.

\section{Methods}

The cross-sectional study sample consisted of 839 (male 572 and female 267) university students residing in student halls at the University of Rajshahi, Bangladesh. The University of Rajshahi is a non-medical and the second largest university in Bangladesh, with students coming from all over the country. The university has sixteen (11 for male and 5 for female) halls of residence accommodating a total of 25000 students (20000 male and 5000 female) at any particular time. Students were interviewed from March to August 2013 using a semi-structured questionnaire containing pre-coded and open-ended questions. The questionnaire had five different parts: (i) general information, (ii) demographic characteristics, (iii) parents' socio-economic characteristics, (iv) general and specific knowledge about TB. This study was approved by National Tuberculosis Control Program (NTP), DGHS Bangladesh and BMRC. We received written consent from all subjects in this study.

\section{Sample size determination}

Since our target population is known (25000 students), the following formula has been used for calculating sample size:

$n=\frac{N}{1+N d^{2}}$, where $n=$ required sample size, $N=$ population size (in here 25000), $d$ = marginal error (we considered, $\mathrm{d}=0.033), 95 \%$ confidence level has been considered. The formula provided that the significant sample size was 839 for this study.

\section{Sampling technique and analysis}

Since our population was heterogeneous and population divided into different groups (male and female), within the group are homogeneous, stratified random sampling with a proportional allocation technique was used for selecting sample from University of Rajshahi, Bangladesh.

The two items 'editing and coding' were processed in computer. Microsoft Excel and Microsoft Word were also used. $X^{2}$-test was utilized in this study to find the association between knowledge about TB and some selected socio-economic and demographic factors. The data was analyzed with Statistical Package for Social Sciences (SPSS) version 17.0. A value of $\mathrm{p}<0.05$ was regarded as statistically significant in the analysis.

\section{Results}

In the present study, we surveyed the knowledge about TB of 839 university students, among them 572 (68.2 \%) and $267(31.8 \%)$ were male and female, respectively. 
$70.4 \%$ and $29.6 \%$ students came from rural and urban area respectively. More than $94 \%$ students declared that they knew the term TB and $5.6 \%$ were confused about the term. Among the subjects $43.7 \%, 18.4 \%, 23.7 \%$ and $14.2 \%$ were first time informed about the term TB from electronic media, print media, relatives and friends and other sources respectively.

More than $30 \%$ students perceived that TB is as noncommunicable disease and $14.8 \%$ students answered that they did not have idea about the term communicable and non-communicable diseases regarding TB. However, $51.5 \%$ respondents answered properly that TB is a communicable disease. The knowledge of communicable disease regarding TB, male had higher percentage (53.7\%) than female (46.8\%) and $\chi^{2}$-test demonstrated that the association between the knowledge of type of TB disease and gender was statistically significant $(\mathrm{p}<0.05)$. The respondents who came from rural environment had higher knowledge $(53.1 \%)$ than urban $(47.6 \%)$ and we noticed that the association between the type of TB disease and residence was significant $(\mathrm{p}<0.05)$. Students who came from single family had more knowledge $(52.2 \%)$ about the communicable disease of $\mathrm{TB}$ than their counterparts $(48.8 \%)$ and the association between the type of TB disease and type of family was significant $(\mathrm{p}<0.05)$ (Table 1$)$.

Among the respondents, $42.8 \%$ believed that TB is a bacterial disease, while others respondents had wrong or no perception about the disease agent. Among the students, female had higher knowledge (48.7 \%) about the agent of TB than male (40.0\%) and we observed that the association between knowledge about the agent of $\mathrm{TB}$ and gender was significant $(\mathrm{p}<0.05)$. Respondents who came from single family had more knowledge $(44.8 \%)$ about the disease agent of $\mathrm{TB}$ than their counterparts $(34.7 \%)$ and the association between these two factors was significant $(\mathrm{p}<0.05)$ (Table 2).

More than $75 \%$ respondents believed that TB is a major public health problem as it spread from person to person through coughing or sneezing. Female students (83.5\%) had higher perception about TB as a public health problem than male $(75.0 \%)$, and the association between the knowledge about TB as public health problems and gender was highly significant $(\mathrm{p}<0.01)$. Students whose father's were service holder had more knowledge $(81.4 \%)$ than their counterparts and the association between the knowledge about TB as public health problem and father occupations was significant $(\mathrm{p}<0.01)$.

Regarding BCG vaccine against TB in children, most of the respondents $(93 \%)$ were aware about the vaccination of TB, among them, female $(76.8 \%)$ were more aware than male $(63.8 \%)$. We noticed that the association between the knowledge about the vaccination of TB and gender was statistically significant $(\mathrm{p}<0.01)$.

More than $97 \%$ respondents strongly believed that TB is a curable disease, among them, male and female were $96.7 \%$ and $99.6 \%$ respectively. The association between the knowledge about curable and gender was significant $(\mathrm{p}<0.01)$. Higher educated parents' son/daughter $(99.2 \%)$ had more knowledge than secondary $(96.5 \%)$, primary (98.5\%) and uneducated (93.9\%), and the association between knowledge about TB as a curable disease and parents' education was significant $(\mathrm{p}<0.01)$ (Table 3$)$.

Students were asked for latent TB as more complex question and only $13.7 \%$ answered positively while $86.3 \%$ respondents did not have idea about latent TB. Male students had higher knowledge (15.4\%) than female (10.1\%), and the association between the knowledge about latent

Table 1 Knowledge about type of TB disease and its association with socio-economic and demographic factors

\begin{tabular}{|c|c|c|c|c|c|c|}
\hline \multirow[b]{2}{*}{ Variables } & \multirow[b]{2}{*}{ Group } & \multicolumn{3}{|c|}{ Is TB communicable disease? } & \multirow[b]{2}{*}{$x^{2}$-value } & \multirow[b]{2}{*}{$p$-value } \\
\hline & & Yes, $432(51.5 \%)$ & No, $283(33.7 \%)$ & No idea, $124(14.8 \%)$ & & \\
\hline \multirow[t]{2}{*}{ Religion } & Muslim & $383(50.9 \%)$ & $255(33.9 \%)$ & $114(15.2 \%)$ & 1.218 & 0.544 \\
\hline & Hindu & $49(56.32 \%)$ & $28(33.7 \%)$ & $10(12.0 \%)$ & & \\
\hline \multirow[t]{2}{*}{ Gender } & Male & 307 (53.7 \%) & $178(31.1 \%)$ & $87(15.2 \%)$ & 5.52 & 0.043 \\
\hline & Female & $125(46.8 \%)$ & $105(39.3 \%)$ & $37(13.9 \%)$ & & \\
\hline \multirow[t]{4}{*}{ Parents' education } & No Education & $71(53.8 \%)$ & $38(28.8 \%)$ & $23(17.4 \%)$ & 7.25 & 0.298 \\
\hline & Primary & $69(50.4 \%)$ & $45(32.8 \%)$ & $23(16.8 \%)$ & & \\
\hline & Secondary & $105(52.5 \%)$ & $61(30.5 \%)$ & $34(17.0 \%)$ & & \\
\hline & Higher & $187(50.5 \%)$ & 139(37.6 \%) & $44(11.9 \%)$ & & \\
\hline \multirow[t]{2}{*}{ Residence } & Rural & $314(53.1 \%)$ & $182(30.8 \%)$ & $95(16.1 \%)$ & 8.42 & 0.015 \\
\hline & Urban & $118(47.6 \%)$ & $101(40.7 \%)$ & $29(11.7 \%)$ & & \\
\hline \multirow[t]{2}{*}{ Type of family } & Single Family & $349(52.2 \%)$ & $231(34.5 \%)$ & $89(13.3 \%)$ & 5.79 & 0.045 \\
\hline & Joint Family & $83(48.8 \%)$ & $52(30.6 \%)$ & $35(20.6 \%)$ & & \\
\hline
\end{tabular}


Table 2 Knowledge about agent of TB and its association with socio-economic and demographic factors

\begin{tabular}{|c|c|c|c|c|c|c|c|}
\hline \multirow[b]{2}{*}{ Variables } & \multirow[b]{2}{*}{ Group } & \multicolumn{4}{|c|}{ Which agent is responsible for TB disease? } & \multirow[b]{2}{*}{$x^{2}$-value } & \multirow[b]{2}{*}{ p-value } \\
\hline & & Bacteria, 359 (42.8 \%) & Virus, $272(32.4 \%)$ & Other, 18 (2.1\%) & Don't know, $190(22.6 \%)$ & & \\
\hline \multirow[t]{2}{*}{ Religion } & Muslim & $320(42.6 \%)$ & $239(41.8 \%)$ & $17(2.3 \%)$ & $176(23.4 \%)$ & 3.294 & 0.349 \\
\hline & Hindu & $39(44.9 \%)$ & $33(37.9 \%)$ & $01(1.2 \%)$ & $14(16.1 \%)$ & & \\
\hline \multirow[t]{2}{*}{ Gender } & Male & $229(40.0 \%)$ & $185(32.3 \%)$ & $14(2.4 \%)$ & $144(25.2 \%)$ & 9.030 & 0.029 \\
\hline & Female & $130(48.7 \%)$ & $87(32.6 \%)$ & $4(1.5 \%)$ & $46(17.2 \%)$ & & \\
\hline \multirow[t]{4}{*}{ Parents' education } & No Education & $48(36.4 \%)$ & $47(35.6 \%)$ & $2(1.5 \%)$ & $35(26.5 \%)$ & 11.992 & 0.214 \\
\hline & Primary & $53(38.7 \%)$ & $42(30.7 \%)$ & $4(2.9 \%)$ & $38(27.7 \%)$ & & \\
\hline & Secondary & $79(39.5 \%)$ & $68(34.0 \%)$ & $5(2.5 \%)$ & $48(24.0 \%)$ & & \\
\hline & Higher & $179(48.4 \%)$ & 115(31.1\%) & 7(1.9\%) & $69(18.6 \%)$ & & \\
\hline \multirow[t]{2}{*}{ Residence } & Rural & $238(40.3 \%))$ & $201(34.0 \%)$ & $15(2.5 \%)$ & 137(23.2 \%) & 6.213 & 0.102 \\
\hline & Urban & $121(48.8 \%)$ & $71(28.6 \%)$ & $3(1.2 \%)$ & $53(21.4 \%)$ & & \\
\hline \multirow[t]{2}{*}{ Type of family } & Single Family & $300(44.8 \%)$ & $213(31.8 \%)$ & $13(1.9 \%)$ & $143(21.4 \%)$ & 6.583 & 0.046 \\
\hline & Joint Family & 59(34.7\%) & 59(34.7\%) & $5(2.9 \%)$ & $47(27.6 \%)$ & & \\
\hline
\end{tabular}

TB and gender was significant $(\mathrm{p}<0.05)$. Students who were smoker had more knowledge $(22.5 \%)$ than their counterparts (12.8\%), and the association between the knowledge about latent TB and smoking status was significant $(\mathrm{p}<0.05)$ (Table 4).

The knowledge on treatment system through DOTs was surveyed among students. More than $90 \%$ of students knew about DOTs while $8.6 \%$ did not have knowledge about treatment system through DOTs. Hindu students had higher knowledge (37.9\%) about DOTs than Muslim (27.4\%), and we observed that the association between knowledge about DOTs and religion was significant $(\mathrm{p}<0.05)$. Male students had more knowledge (30.9\%) than female (23.2\%), the association between the knowledge about DOTs and gender was significant $(\mathrm{p}<0.05)$. Students who came from single family had more knowledge (30.2 \%) than their counterparts (21.8\%). We noticed that the association between the knowledge about DOTs and type of family was significant $(\mathrm{p}<0.05)$ (Table 5).

\section{Discussion}

In the present study, we surveyed the knowledge among non-medical university students about $\mathrm{TB}$, particularly on common symptoms [1], disease agent, communicable or non-communicable, latent $\mathrm{TB}$, vaccination against $\mathrm{TB}$, treatment system etc. This study also examined the perception of respondents about TB as a public health problem, source of gaining knowledge, urban-rural and male-female ratio, parents' education and income etc. Most of the students declared that they heard the term TB from various sources, such as electronic media, print

Table 3 Knowledge about the TB as curable disease and its association with socio-economic and demographic factors

\begin{tabular}{|c|c|c|c|c|c|}
\hline \multirow[b]{2}{*}{ Variables } & \multirow[b]{2}{*}{ Group } & \multicolumn{2}{|c|}{ Do you think about TB as curable disease? } & \multirow[b]{2}{*}{$x^{2}$-value } & \multirow[b]{2}{*}{ p-value } \\
\hline & & Yes $819(97.6 \%)$ & No 20 (2.4\%) & & \\
\hline \multirow[t]{2}{*}{ Religion } & Muslim & $733(97.5 \%)$ & $19(2.5 \%)$ & 0.636 & 0.425 \\
\hline & Hindu & $86(98.9 \%)$ & $01(1.1 \%)$ & & \\
\hline \multirow[t]{2}{*}{ Gender } & Male & $553(96.7 \%)$ & 19(3.3 \%) & 6.795 & 0.009 \\
\hline & Female & $266(99.6 \%)$ & $01(.4 \%)$ & & \\
\hline \multirow[t]{4}{*}{ Parents' education } & No Education & $124(93.9 \%)$ & $08(6.1 \%)$ & 13.176 & 0.004 \\
\hline & Primary & $135(98.5 \%)$ & $02(1.5 \%)$ & & \\
\hline & Secondary & 193(96.5\%) & $07(3.5 \%)$ & & \\
\hline & Higher & $367(99.2 \%)$ & $03(.8 \%)$ & & \\
\hline \multirow[t]{2}{*}{ Residence } & Rural & $578(97.8 \%)$ & $13(2.2 \%)$ & 0.291 & 0.589 \\
\hline & Urban & $241(97.2 \%)$ & $07(2.8 \%)$ & & \\
\hline \multirow[t]{2}{*}{ Type of family } & Single Family & $653(97.6 \%)$ & $16(2.4 \%)$ & 0.001 & 0.976 \\
\hline & Joint Family & $166(97.6 \%)$ & $4(2.4)$ & & \\
\hline
\end{tabular}


Table 4 Knowledge about latent TB and its association with socio-economic and demographic factors

\begin{tabular}{|c|c|c|c|c|c|}
\hline \multirow[b]{2}{*}{ Variables } & \multirow[b]{2}{*}{ Group } & \multicolumn{2}{|c|}{ Do you know about latent TB? } & \multirow[b]{2}{*}{$x^{2}$-value } & \multirow[b]{2}{*}{ p-value } \\
\hline & & Yes, 115 (13.7 \%) & No, $724(86.3 \%)$ & & \\
\hline \multirow[t]{2}{*}{ Religion } & Muslim & 103(13.7\%) & $649(86.3 \%)$ & 0.001 & 0.980 \\
\hline & Hindu & $12(13.79 \%)$ & $75(86.21 \%)$ & & \\
\hline \multirow[t]{2}{*}{ Gender } & Male & $88(15.4 \%)$ & $484(84.6 \%)$ & 4.28 & 0.039 \\
\hline & Female & $27(10.1 \%)$ & $240(89.9 \%)$ & & \\
\hline \multirow[t]{4}{*}{ Parents' education } & No Education & $15(11.4 \%)$ & $117(88.6 \%)$ & 2.41 & 0.492 \\
\hline & Primary & $16(11.7 \%)$ & $121(88.3 \%)$ & & \\
\hline & Secondary & $33(16.5 \%)$ & $167(83.5 \%)$ & & \\
\hline & Higher & $51(13.8 \%)$ & $319(86.2 \%)$ & & \\
\hline \multirow[t]{2}{*}{ Residence } & Rural & $83(14.0 \%)$ & $508(86.0 \%)$ & .192 & 0.661 \\
\hline & Urban & $32(12.9 \%)$ & $216(87.1 \%)$ & & \\
\hline \multirow[t]{2}{*}{ Type of family } & Single Family & $94(14.1 \%)$ & $575(85.9 \%)$ & 0.330 & 0.565 \\
\hline & Joint Family & $21(12.4 \%)$ & 149(87.6 \%) & & \\
\hline
\end{tabular}

media, relatives and friends. Similar results were found among other people in Rajshahi city including students [18]. In the current study demonstrated that nearly half of the students gathered knowledge about TB from electronic media, and it was a strong media to communicate people at all level to aware, inform and guide them for receiving information and services with free of cost from their nearest distance. Friends and relatives were also playing a vital role in disseminating information to others. In addition, parent's education have played a significant role to increase their children's knowledge about communicable disease such as TB. Different sessions, meetings, workshops, drama, rally was influencing others as discussion matter. Printed media, bill boards, leaflets; posters were also important media to inform about TB. In the present study have shown that nearly half of the students properly knew that TB is a communicable disease and it spread from person to person. A remarkable number of students had no knowledge on TB as communicable disease. It indicated that less involvement of students in TB related sessions, meetings or workshops. Though government as well as its several partner NGOs were working for advocacy, communication and social mobilization (ACSM) in Rajshahi district, they needed to perform adequate sessions or meeting with non medical university students. We found that the students who came from rural area had more knowledge regarding communicable disease than their counterpart. This might be happened due to frequent advertisement about communicable disease through Bangladesh television (BTV) which was largely observed by rural people. The urban people usually enjoyed other television channels like dish television. Now

Table 5 Knowledge about DOTs program and its association with socio-economic and demographic factors

\begin{tabular}{|c|c|c|c|c|c|}
\hline \multirow[b]{2}{*}{$\underline{\text { Variables }}$} & \multirow[b]{2}{*}{ Group } & \multicolumn{2}{|c|}{ Do you know about DOTs Program? } & \multirow[b]{2}{*}{$x^{2}$-value } & \multirow[b]{2}{*}{ P-value } \\
\hline & & Yes, $767(91.4 \%)$ & No, $72(8.6 \%)$ & & \\
\hline \multirow[t]{2}{*}{ Religion } & Muslim & $206(27.4 \%)$ & $546(72.6 \%)$ & 4.250 & 0.039 \\
\hline & Hindu & $33(37.9 \%)$ & $54(62.1 \%)$ & & \\
\hline \multirow[t]{2}{*}{ Gender } & Male & 177(30.9 \%) & 395(69.1\%) & 5.330 & 0.021 \\
\hline & Female & $62(23.2 \%)$ & $205(76.8 \%)$ & & \\
\hline \multirow[t]{4}{*}{ Parents' education } & No Education & $40(30.3 \%)$ & $92(69.7 \%)$ & 0.354 & 0.950 \\
\hline & Primary & $38(27.7 \%)$ & $99(72.3 \%)$ & & \\
\hline & Secondary & $58(29.0 \%)$ & $142(71.0 \%)$ & & \\
\hline & Higher & $103(27.8 \%)$ & $267(72.2 \%)$ & & \\
\hline \multirow[t]{2}{*}{ Residence } & Rural & $177(29.9 \%)$ & $414(70.1 \%)$ & 2.101 & 0.147 \\
\hline & Urban & $62(25.0 \%)$ & $186(75.0 \%)$ & & \\
\hline \multirow[t]{2}{*}{ Type of family } & Single Family & $202(30.2 \%)$ & $467(69.8 \%)$ & 4.728 & 0.030 \\
\hline & Joint Family & $37(21.8 \%)$ & $133(78.2 \%)$ & & \\
\hline
\end{tabular}


a day, dish TV channels are expanding to rural areas of Bangladesh. So, it is necessary to widely utilize dish TV channels as electronic media for TB related advertisement. Poverty, illiteracy, higher fertility has higher chance of developing TB. Once TB develops in any family, all members of the family become experienced and gained knowledge about symptoms, services and management of TB. In this study, nearly half of the students believed that TB is a bacterial disease while other had no knowledge or wrong perception. It may indicate less inclusion of TB related disease idea in general education curriculum. In developing countries like Bangladesh, more than half of whole populations are infected with TB as a latent TB. This latent TB has the chance of reactivation to active disease at any time when environment is favorable. But unfortunately the knowledge about latent TB among students was very poor. Poor nutrition, diabetes or immunosuppressive drugs, smoking or certain diseases can reactivate the latent TB. University students should know more about latent TB and its environmental condition. In the present study demonstrated that male had more aware than female about the knowledge on TB disease, latent TB and DOTs, on the other hand, female had more knowledge on disease agent and its curable than male. This gender difference may indicate the cultural and life styles in Bangladesh. The most of the time, mother as well as daughter usually stay at home and more prone to enjoy TV from where they receive limited information. Comparatively they are less exposed to market or public places. On the other hand, males are more exposed to markets, hospitals and other important public places. So, they have more chance to gain information from various sources such as bill boards, posters and friends along with TV.

In case of type of family, this study showed that the participants came from single family had more knowledge about TB disease, its agent, and treatment systems than who came from joint family. This may linked to parent's income, education, media and other facilities. In single family, parents had more time to care their children and discuss about the general issues such as communicable diseases.

Almost all Bangladeshi has adopted with expanded program on immunization (EPI) and our study showed that with the success of EPI in Bangladesh, most of the respondents believed that BCG vaccination is effective against childhood TB. Of them, female were more aware than male. Previously, people in Bangladesh thought that $\mathrm{TB}$ is not curable. Now-a-days almost all Bangladeshi strongly believe that TB is a curable disease through ACSM activities of NTP. Most of the participants knew about the DOTs system for TB treatment, and the respondents who followed Hindu religion had more knowledge than Muslim. As public health concern, most of the respondents believed that $\mathrm{TB}$ is a major public health problem as it spread from person to person through coughing or sneezing.

\section{Conclusions}

In this study 839 students were surveyed their knowledge about $\mathrm{TB}$ and established the association between the knowledge about TB and some selected socio-economic and demographic factors. This study revealed that more than half of students believed that TB is communicable disease, most of the students correctly answered about TB vaccination. More than two-third students agreed that TB is major health problem in Bangladesh. Most of the students believed that TB is curable disease, and about half of the students knew that bacteria are the agent for TB. A few students had idea about latent TB and most of the respondents had heard about DOTs program. Poor knowledge about TB was noted among the students who came from urban areas, and joint family. Students who were smoker and whose parents were higher educated had more knowledge on latent $\mathrm{TB}$ and curable respectively than their counterparts.

\section{Abbreviations}

TB: Tuberculosis; WHO: World Health Organization; HIV: Human Immune Deficiency Virus; HBCs: High Burden Countries; DGHS: Directorate General of Health Services; NTP: National Tuberculosis Control Program; DR: Drug Resistant; DOT: Directly Observed Treatment; SPSS: Statistical Package for Social Sciences; TV: Television; BTV: Bangladesh Television; EPI: Expanded program on immunization; ACSM: Advocacy, Communication and Social Mobilization.

\section{Competing interests}

The authors declare that they have no competing interests.

\section{Authors' contributions}

All authors read and approved the final manuscript. MGH, MAS and NI designed the study project and collected data. MR, MGH and MAS conducted the data analysis and wrote the manuscript. MRK, MRI and TK made critical revisions of the manuscript.

\section{Acknowledgements}

The authors gratefully acknowledge the authority of Students' Residence Hall, University of Rajshahi, Bangladesh for giving permission to take data from students.

\section{Author details}

${ }^{1}$ Department of Population Science \& Human Resource Development, University of Rajshahi, Rajshahi 6205, Bangladesh. ${ }^{2}$ Divisional TB Expert, National Tuberculosis Control Program, Directorate General of Health Services, Dhaka, Bangladesh. ${ }^{3}$ Development Association for self-reliance, Communication and Health, Rajshahi 6201, Bangladesh. ${ }^{4}$ Department of Statistics, University of Rajshahi, Rajshahi 6205, Bangladesh. ${ }^{5}$ National Orthopaedic Centre of Excellence for Research and Learning (NOCERAL), Department of Orthopaedic Surgery, University of Malaya, Kuala Lumpur, Malaysia.

Received: 20 December 2014 Accepted: 17 July 2015

Published online: 28 July 2015

\section{References}

1. Directorate General of Health Services (DGHS). National Tuberculosis Control Program (NTP), National Guidelines and Operation Manual for Tuberculosis Control; $4^{\text {th }}$ and $5^{\text {th }}$ editions-2011 and 2013

2. World Health Organization (WHO). Global TB Repot. 2013. 
3. Huang $Y$, Zhong JM, Chen SH, Chen B, Wang XM. Investigation analysis on public awareness of tuberculosis knowledge in Zhejiang province. Zhonghua Yu Fang Yi Xue Za Zhi. 2012;46(4):352-4.

4. Diallo S, Diarra B, Diop S, Toloba Y, Berthé F, Sissoko B, et al. Knowledge of the Bamako general population on tuberculosis. Mali Med. 2009;24(1):48-51.

5. Reddy V, Bennadi D, Gaduputi S, Kshetrimayum N, Siluvai S. Oral health related knowledge, attitude, and practice among the pre-university students of Mysore city. J Int Soc Prev Community Dent. 2014;4(3):154-8. doi:10.4103/2231-0762.142012.

6. Orrett FA, Shurland SM. Knowledge and awareness of tuberculosis among pre-university students in Trinidad. J Community Health. 2001;26(6):479-85.

7. Naidoo S, Taylor M. Association between South African high-school learners' knowledge about tuberculosis and their intention to seek healthcare. Glob Health Action. 2013;6:21699. doi:10.3402/gha.v6i0.21699.

8. Tanimowo MO. Knowledge, attitudes and practices regarding tuberculosis among senior secondary school students. East Afr Med J. 1999;76(1):47-50.

9. Montagna MT, Napoli C, Tafuri S, Agodi A, Auxilia F, Casini B, et al. Knowledge about tuberculosis among undergraduate health care students in 15 Italian universities: a cross-sectional study. BMC Public Health. 2014;14(1):970. doi:10.1186/1471-2458-14-970.

10. Behnaz F, Mohammadzade G, Mousavi-e-Roknabadi RS, Mohammadzadeh M. Assessment of knowledge, attitudes and practices regarding tuberculosis among final year students in Yazd, Central Iran. J Epidemiol Glob Health. 2014;4(2):81-5. doi:10.1016/j.jegh.2013.09.003.

11. Laurenti P, Federico B, Raponi M, Furia G, Ricciardi W, Damiani G. Knowledge, experiences, and attitudes of medical students in Rome about tuberculosis. Med Sci Monit. 2013;19:865-74. doi:10.12659/MSM.889515.

12. Zhao Y, Ehiri J, Li D, Luo X, Li Y. A survey of TB knowledge among medical students in Southwest China: is the information reaching the target? BMJ Open. 2013;3(9), e003454. doi:10.1136/bmjopen-2013-003454.

13. Akin S, Gorak G, Unsar S, Mollaoglu M, Ozdilli K, Durna Z. Knowledge of and attitudes toward tuberculosis of Turkish nursing and midwifery students. Nurse Educ Today. 2011;31(8):774-9. doi:10.1016/j.nedt.2010.12.019.

14. Smolovic M, Pesut D, Bulajic M, Simic M. Knowledge and attitudes towards tuberculosis in non-medical students University of Belgrade. Pneumologia. 2012;61 (2):88-91.

15. Muñoz Sánchez Al, Bertolozzi MR. Functioning of the concept of vulnerability to tuberculosis amongst university students. Cien Saude Colet. 2011;16(2):669-75.

16. Khandoker A, Khan MM, Krämer A, Mori M. Knowledge about tuberculosis transmission among ever-married women in Bangladesh. Int J Tuberc Lung Dis. 2011;15(3):379-84.

17. Croft RP, Croft RA. Knowledge, attitude and practice regarding leprosy and tuberculosis in Bangladesh. Lepr Rev. 1999;70(1):34-42.

18. Sayem MA, Islam MM. Activities of NTP, Bangladesh: A Special Focus on Promotional Activities. Internship report. Master of Business Administration Institute of Business Administration, University of Rajshahi. 2013, Nov 27.

\section{Submit your next manuscript to BioMed Central and take full advantage of:}

- Convenient online submission

- Thorough peer review

- No space constraints or color figure charges

- Immediate publication on acceptance

- Inclusion in PubMed, CAS, Scopus and Google Scholar

- Research which is freely available for redistribution 